\title{
Nitric oxide and histone deacetylases modulate cocaine-induced mu-opioid receptor levels in PC12 cells
}

\author{
Warren Winick-Ng ${ }^{1}$, Francesco Leri ${ }^{2}$ and Bettina E Kalisch ${ }^{{ }^{*}}$
}

\begin{abstract}
Background: Cocaine exposure has been reported to alter central $\mu$-opioid receptor (MOR) expression in vivo. The present study employed an in vitro cellular model to explore possible mechanisms that may be involved in this action of cocaine.

Methods: To assess the effects of cocaine on MOR levels, two treatment regimens were tested in PC12 cells: single continuous or multiple intermittent. MOR protein levels were assessed by western blot analysis and quantitative PCR was used to determine relative MOR mRNA expression levels. To evaluate the role of nitric oxide (NO) and histone acetylation in cocaine-induced MOR expression, cells were pre-treated with the NO synthase inhibitor $\mathrm{N}^{\omega}$-nitro-L-arginine methylester (L-NAME) or the non-selective histone acetyltransferase inhibitor curcumin.

Results: Both cocaine treatment regimens significantly increased MOR protein levels and protein stability, but only multiple intermittent treatments increased MOR mRNA levels as well as c-fos mRNA levels and activator protein 1 binding activity. Both regimens increased NO production, and pre-treatment with L-NAME prevented cocaine-induced increases in MOR protein and mRNA levels. Single and multiple cocaine treatment regimens inhibited histone deacetylase activity, and pre-treatment with curcumin prevented cocaine-induced up-regulation of MOR protein expression.

Conclusions: In the PC12 cell model, both NO and histone deacetylase activity regulate cocaine-induced MOR expression at both the transcriptional and post-transcriptional levels. Based on these novel findings, it is hypothesized that epigenetic mechanisms are implicated in cocaine's action on MOR expression in neurons.
\end{abstract}

Keywords: Cocaine, PC12 cells, Histone acetylation, Nitric oxide, Mu-opioid receptor

\section{Background}

Endogenous opioid systems are involved in several aspects of cocaine addiction [1-5], and several studies have indicated that cocaine increases $\mu$-opioid receptor (MOR) mRNA and peptide expression [6-11] in regions of the brain known to regulate incentive motivation and stress reactivity [12-14]. In rats, cocaine-induced increases in MOR mRNA expression have been consistently observed in the ventral striatum $[15,16]$, a region of the brain critical to drug motivated behaviors $[17,18]$. Furthermore, PET studies in abstinent cocaine users have established

\footnotetext{
* Correspondence: bkalisch@uoguelph.ca

${ }^{1}$ Department of Biomedical Sciences, University of Guelph, Guelph, Ontario N1G 2W1, Canada

Full list of author information is available at the end of the article
}

correlations between elevations in MOR binding in mesocorticolimbic areas and intensity of cocaine cravings [19-21]. These data suggest the importance of elucidating the molecular mechanisms through which cocaine alters MOR levels in the central nervous system.

The experiments reported in this manuscript were designed to investigate two possible, and related, mechanisms. First, cocaine administration elevates concentrations of nitric oxide $(\mathrm{NO})$ in the rat brain [22,23], and both cocaine and NO increase levels, and binding activity, of members of the activator protein 1 (AP-1) transcription factor family [24-32]. Because the promoter region of the MOR gene contains consensus sequences for AP-1 transcription factors [33], it is possible that cocaine modulates MOR expression via alterations in NO and AP-1 activity.

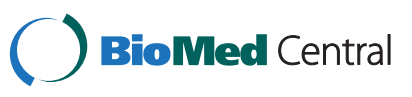


Second, NO also decreases the activity of histone deacetylases (HDACs) [34,35], enzymes implicated in the behavioral effects of cocaine in rats [36,37], as well as in morphine-induced MOR expression [38,39]. HDACs affect chromatin structure through the removal of acetyl groups from histones [40-42], and thus contribute to gene transcription [43-47]. Therefore, it is also likely that cocaine modulates MOR expression via alterations in histone acetylation.

These experiments employed PC12 cells to investigate the role of NO and HDACs in cocaine-induced alterations of MOR expression. This in vitro cellular model was selected because PC12 cells express the MOR gene [48-50], their NO pathway has been fairly well characterized [51-54], and they are sensitive to changes in HDACs activity [55]. Three main results were obtained. First, cocaine increased MOR protein expression and protein stability after both single continuous and multiple intermittent treatment regimens, but only the multiple intermittent treatment regimen increased expression of MOR and c-fos mRNAs, as well as AP-1 binding activity. Second, NO was identified as an important modulator, as cocaine increased $\mathrm{NO}$ production, and the NO synthase (NOS) inhibitor $\mathrm{N}^{\omega}$-nitro-L-arginine methylester (L-NAME) attenuated cocaine-induced increases in MOR protein and mRNA expression. Third, it was found that cocaine decreased HDACs activity, and inhibition of histone acetyltransferase (HAT) attenuated cocaine-induced increases in MOR protein expression following both treatment regimens.

\section{Methods}

\section{Materials}

Dulbecco's modified Eagle medium (DMEM), horse serum, gentamycin, DNAse I, Oligo dT, Superscript II, primers, Platinum Taq and Lipofectamine 2000 were purchased from Invitrogen (Mississauga, ON, Canada) and fetal bovine serum (FBS) was obtained from HyClone Laboratories (Logan, UT, USA). Cocaine $\mathrm{HCl}$ was purchased from Dumex (Toronto, ON, Canada), L-NAME, curcumin, and mouse monoclonal anti- $\alpha$-tubulin were purchased from Sigma Aldrich (St. Louis, MO, USA). The complete mini tablets were purchased from Roche Diagnostics (Laval, QC, Canada), the sodium dodecyl sulfate (SDS) sample buffer, DTT, and protein standards were obtained from New England Biolabs (Ipswich, MA) and the polyclonal MOR antibody was from Abcam (Cambridge, MA, USA) or Santa Cruz Biotechnology Inc. (Santa Cruz, CA, USA). Luminol was also purchased from Santa Cruz. Hybond-C blotting membranes, sheep anti-mouse IgG and enhanced chemiluminescence (ECL) kit were obtained from Amersham/GE Health Care (Piscataway, NJ, USA), poly-D-lysine was from BD Biosciences (Mississauga, ON, Canada) and 4,5-diaminofluorescein diacetate (DAF-2 DA) was purchased from Calbiochem (San Diego, CA, USA). Syber Green PCR master mix was obtained from Qiagen (Toronto, ON, Canada) and the HDAC Assay kit was from Active Motif (Carlsbad, CA, USA). The PathDetect pAP-luciferase reporter plasmid was obtained from Stratagene (La Jolla CA, USA) and the Luciferase Assay and Galacto-Light (Tropix) kits were from Promega (Madison, WI, USA) and Applied Biosystems (Bedford, MA, USA), respectively. All other chemicals were molecular or electrophoresis grade and obtained from Fisher Scientific (Ottawa, ON, Canada) or DiaMed Laboratories (Mississauga, ON, Canada).

\section{Cell culture, viability and treatments}

PC12 cells were maintained in DMEM containing 5\% FBS, $5 \%$ horse serum and $50 \mu \mathrm{g} / \mathrm{mL}$ gentamycin at $37^{\circ} \mathrm{C}$ in $5 \% \mathrm{CO}_{2}$. To evaluate the effects of cocaine, $\mathrm{NO}$ synthase (NOS) inhibitors, and curcumin on MOR protein and mRNA levels, cells were plated on Corning ${ }^{\circledR} 60 \mathrm{~mm}$ dishes at a density of 1.0 million cells per plate for protein, and 1.5 million cells per plate for RNA. For the AP1 study, PC12 cells were plated on 12-well culture dishes at a concentration of $2.0 \times 10^{5}$ cells per well. For NO production imaging, $\mathrm{PC} 12$ cells were plated on 6-well culture dishes containing poly-D-lysine coated coverslips at a concentration of $2.0 \times 10^{5}$ cells per well. For nuclear extraction, PC12 cells were plated on $100 \mathrm{~mm}$ culture dishes at a concentration of $4.0 \times 10^{6}$ cells per plate. All plating was performed $24 \mathrm{~h}$ prior to any treatment.

The effects of cocaine were determined by exposing PC12 cells to various concentrations of cocaine using two different treatments. The doses of cocaine selected for this study $(10,100$, and $500 \mu \mathrm{M})$ were based on previous reports investigating the effects of cocaine on morphological changes and proto-oncogene expression in PC12 cells [56]. Two treatment regimens were chosen based on previous findings indicating that different exposure patterns can differentially affect MOR binding affinity and receptor density in several regions of the rat brain $[57,58]$. These treatments were: single continuous treatment (SCT) or repeated intermittent treatment (RIT) (see Table 1). The latter regimen included 3 daily treatments, each lasting $30 \mathrm{~min}$, separated by $60 \mathrm{~min}$ exposures to cocaine-free media. Cells were harvested $72 \mathrm{~h}$ after the beginning of treatment, except where otherwise indicated.

PC12 cell viability was assessed in control cells and those exposed to $500 \mu \mathrm{M} \mathrm{SCT}$ or $100 \mu \mathrm{M}$ RIT with cocaine for $72 \mathrm{~h}$ by the reduction of 3-(4,5-dimethylthiazole2-yl)-2,5-diphenyltetrazolium bromide (MTT) as described by Cheung et al. [59]. Culture media was replaced with media containing MTT $(0.5 \mathrm{mg} / \mathrm{mL}$ final concentration) and the cells were incubated at $37^{\circ} \mathrm{C}$ for $30 \mathrm{~min}$. The reduced formazan product was lysed from the cells using 
a $100 \%$ dimethylsulfoxide solution and the absorbance was subsequently measured at $570 \mathrm{~nm}$ using the FLUOstar Optima plate-reader (BMG, Fisher Scientific).

The effect of NOS and HAT inhibitors was determined by pre-treating PC12 cells with inhibitor, for $1 \mathrm{~h}$ prior to cocaine exposure. We determined previously that NGF increases NOS activity and NO production in PC12 cells and that this increase is attenuated when cells are pretreated with $20 \mathrm{mM}$ L-NAME [53]. Therefore, cells were pretreated with this dose of L-NAME to examine the involvement of $\mathrm{NO}$ in the cocaine-induced expression of MOR. Cells were also pretreated with 1,3 or $5 \mu \mathrm{M}$ of the non-selective HAT inhibitor curcumin, based on a previous report by Siddiqui et al. [60], which explored the impact of curcumin on oxidative stress in PC12 cells. Curcumin was selected for these experiments because it inhibits HAT in both in vitro and in vivo models [61-63] and it modulates cocaine place preference in rats [36]. For RIT, each $30 \mathrm{~min}$ cocaine treatment was followed by the addition of PC12 cell culture media containing only L-NAME (20 mM) or curcumin $(1,3,5 \mu \mathrm{M})$.

\section{Immunoblot analysis}

Control and treated PC12 cells were lysed in $250 \mu \mathrm{L}$ of radioimmunoprecipitation assay (RIPA) buffer (final concentration: $50 \mathrm{mM}$ Tris, $150 \mathrm{mM} \mathrm{NaCl}, 1 \% \mathrm{NP}-40$, $0.25 \%$ sodium deoxycholate, $0.5 \%$ SDS, $1 \mathrm{mM}$ each of EDTA, sodium fluoride, sodium orthovanadate and protease inhibitor (1 Complete Mini Tablet (Roche Diagnostics)/10 mL], pH 7.4). Samples were rocked on ice for 15 min, sonicated, centrifuged at $17530 \mathrm{~g}$ for $15 \mathrm{~min}$ and the protein content of the supernatant determined by the method of Bradford [64]. Cell lysates $(100 \mu \mathrm{g})$ were then boiled in SDS sample buffer (final concentration: 62.5 mM Tris-HCl; pH 6.8, 2\% SDS, $42 \mu \mathrm{M}$ DTT, $10 \%$ glycerol and $0.01 \%$ phenol red) and loaded onto a $10 \%$ SDS/polyacrylamide gel.

Following electrophoresis, proteins were transferred onto nitrocellulose membranes (Hybond-C) using a Trans-blot semidry transfer unit (Bio-Rad Laboratories, Mississauga, ON, Canada) with transfer buffer (final concentration: $28 \mathrm{mM}$ Tris, $39 \mathrm{mM}$ glycine and 20\% methanol, $\mathrm{pH}$ 9.2). Membranes were blocked in $2.5 \%$ or $5 \%$ non-fat milk in tris-buffered saline (TBS) containing $0.1 \%$ Tween-20 (TBS-T) for $1 \mathrm{~h}$. Blots were then incubated in 1:750 rabbit MOR antibody in 1\% bovine serum albumin (BSA) in TBS-T for $2 \mathrm{~h}$ (Abcam), or in 1:200 rabbit MOR antibody in $1 \%$ non-fat milk in TBS-T (Santa Cruz) overnight. Antibody detection was achieved using 1:2500 horseradish peroxidase-conjugated donkey anti-rabbit IgG in either $1 \%$ BSA or $5 \%$ non-fat milk in TBS-T for $1 \mathrm{~h}$, followed by ECL or luminol.

Membranes were scanned using the STORM 860 (Molecular Dynamics, subsidiary of Amersham) for ECL, or the Fluorchem 9900 imaging system (Alpha Innotech, Santa Clara, CA, USA) for luminol. Bands were analyzed densitometrically using Imagequant (Molecular Dynamics) or Fluorchem 9900 software. Blots were stripped with $62.5 \mathrm{mM}$ Tris, $\mathrm{pH}$ 6.7, containing 2\% SDS and 100 $\mathrm{mM}$ 2-mercaptoethanol at $50^{\circ} \mathrm{C}$ for $20 \mathrm{~min}$. Membranes were then rinsed in TBS for at least $4 \mathrm{~h}$ before blocking with $5 \%$ milk in TBS-T for $1 \mathrm{~h}$ and reprobing with 1:50 000 mouse monoclonal anti- $\alpha$ tubulin antibody overnight. Blots were then exposed to 1:2500 goat anti-mouse IgG-horse radish peroxidase conjugated secondary antibody, in 5\% milk in TBS-T and the protein bands visualized as described above.

\section{MOR half-life analysis}

Following $72 \mathrm{~h}$ of treatment, control and SCT or RIT PC12 cells were exposed to $10 \mu \mathrm{g} / \mathrm{mL}$ cycloheximide [65], a de novo protein translation inhibitor, for 4, 8, 12, 24 and $48 \mathrm{~h}$. Cells were then lysed in $250 \mu \mathrm{L}$ RIPA buffer, and western blot analysis for MOR and $\alpha$-tubulin was performed as described above.

\section{Analysis of NO production}

NO production was assessed using the fluorescent probe DAF-2 DA. PC12 cells were treated with cocaine (100 or $500 \mu \mathrm{M})$ in the presence or absence of $20 \mathrm{mM}$ L-NAME for 3 days, washed once with media and loaded with 10 $\mu \mathrm{M}$ DAF-2 DA in $1 \mathrm{~mL}$ culture media. Following $2 \mathrm{~h}$ of incubation cells were washed 4 times with $2 \mathrm{~mL}$ media and DAF-2 fluorescence was visualized using an Olympus IX-81 fluorescence microscope (excitation at 488 $\mathrm{nm}$, emission at $520 \mathrm{~nm}$ ) with an Olympus LucPlan FL 0.40 aperture lens (at $20 \mathrm{x}$ magnification) in phosphate buffered saline at room temperature. Digital images were captured using a Cascade 512F camera (Photometrics, Tucson, AZ, USA), and processed in Q-Capture and Adobe Photoshop 5.0.

\section{qPCR and PCR analysis}

In our previous studies of gene expression in PC12 cells, changes in mRNA typically occurred 24 to $36 \mathrm{~h}$ prior to changes in protein expression [53]. Therefore we initially examined MOR mRNA following $48 \mathrm{~h}$ of SCT and RIT with cocaine. Control and treated PC12 cells were lysed in $1 \mathrm{~mL}$ of Trizol reagent to obtain total RNA. The extracted RNA was treated with DNase I and reverse transcribed using superscript II with oligo-dT as the primer for 75 $\min$ at $43^{\circ} \mathrm{C}$ [53]. The resulting cDNA was then used for real time PCR (qPCR) using a LightCycler (Roche). qPCR was performed using $1 \mu \mathrm{L}$ cDNA and $9 \mu \mathrm{L}$ of QuantiTect SYBR Green PCR master mix. There was a 15 min incubation period at $95^{\circ} \mathrm{C}$ prior to the first cycle, and a melting curve was obtained for each sample following the final cycle [65]. Primer pairs and cycling conditions were: $\beta$-2- 
microglobulin (Genbank Accession number NM_012512): 5' primer: 5'-TGACCGTGATCTTTCTGGTG-3' and 3' primer: 5'-ATCTGAGGTGGGTGGAACTG-3', 45 cycles of $95^{\circ} \mathrm{C}: 15 \mathrm{~s}, 55^{\circ} \mathrm{C}: 25 \mathrm{~s}, 72^{\circ} \mathrm{C}: 15 \mathrm{~s}$; MOR coding region (Genbank Accession Number U02083.1): 5' primer: 5'CTGTGTGTTACGGCCTGATG-3' and 3' primer: 5'ATGCAGAAGTGCCAGGAAAC-3, 55 cycles of $95^{\circ} \mathrm{C}$ : $15 \mathrm{~s}, 52^{\circ} \mathrm{C}$ : $25 \mathrm{~s}, 72^{\circ} \mathrm{C}$ : $15 \mathrm{~s}$. After each cycle, fluorescent activity was determined, and a final crossing point (threshold cycle, $\mathrm{C}_{\mathrm{T}}$ ) was calculated. Steady-state MOR mRNA levels relative to $\beta-2$ microglobulin were determined with RelQuant software

To qualitatively observe the effect of cocaine on $c$-fos levels, total RNA was extracted from control and treated PC12 cells as described above $0.5,1$ or $2 \mathrm{~h}$ after the final 30 min $100 \mu \mathrm{M}$ cocaine treatment on the first day of RIT. Following reverse transcription, $5 \mu \mathrm{L}$ cDNA was combined with $45 \mu \mathrm{L}$ of master mix containing (final concentration): $15 \mathrm{mM} \mathrm{MgCl} 2,10 \mathrm{mM}$ dNTPs, $5 \mu \mathrm{M}$ of forward and reverse primers, $10 \times$ PCR buffer, $0.2 \mu \mathrm{L}$ of Platinum Taq and water $[53,65]$. Each PCR was performed with an initial $2 \mathrm{~min}, 95^{\circ} \mathrm{C}$ strand separation and a final $2 \mathrm{~min}, 72^{\circ} \mathrm{C}$ elongation. Primer pairs and cycling conditions were: $\beta$-actin (Genbank Accession number NM_031144): 5' primer 5'-TCATGAAGTGTGACGGTTGACATCCGT-3' and 3' primer 5'-CCTAGAAGATTTGCGGTGCACGATG-3', 30 cycles of $95^{\circ} \mathrm{C}$ : $30 \mathrm{~s}, 55^{\circ} \mathrm{C}: 30 \mathrm{~s}, 72^{\circ} \mathrm{C}$ : $45 \mathrm{~s}$; c-fos coding region (Genbank Accession number NM_022197 XM_234422): 5' primer: 5'-ACGCGGACTACGAGGCGTCA-3' and 3' primer: 5'-GCTCTGGTCTGCGATGGGGC-3', 40 cycles of $95^{\circ} \mathrm{C}: 30 \mathrm{~s}, 55^{\circ} \mathrm{C}: 30 \mathrm{~s}, 72^{\circ} \mathrm{C}: 45 \mathrm{~s}$. PCR products were separated on a $1.5 \%$ agarose gel stained with ethidium bromide. Fragments were visualized using the Pharmacia Biotech ImageMaster VDS, and images captured were processed in Microsoft Office Picture Manager. To quantify steady-state mRNA levels qPCR was performed as described above and analysis of $c$-fos levels relative to $\beta-2$ microglobulin determined using RelQuant software.

\section{AP-1 luciferase activity}

PC12 cells were fed with antibiotic free media $30 \mathrm{~min}$ prior to transfection. For each well $1.0 \mu \mathrm{g}$ luciferase reporter plasmid containing 7 AP-1 transcription factor binding elements was incubated with $0.5 \mu \mathrm{g}$ of a pSV- $\beta$ galactosidase $(\beta$-gal) plasmid and $2 \mu \mathrm{L}$ Lipofectamine2000 in $100 \mu \mathrm{L}$ OptiMEM for $30 \mathrm{~min}$ at room temperature [51]. The mixture was added to PC12 cells and the plates returned to the cell culture incubator for $5 \mathrm{~h}$. The transfection medium was replaced with regular PC12 culture medium and the cells returned to the incubator overnight. Following $6 \mathrm{~h}$ of SCT or RIT with cocaine or $50 \mathrm{ng} / \mathrm{mL}$ NGF (used as a positive control for AP-1 activation [51]) treatment, PC12 cells were lysed with $200 \mu \mathrm{L} 1 \mathrm{X}$ passive lysis buffer (Promega). Lysates were incubated for $30 \mathrm{~min}$ at $4^{\circ} \mathrm{C}$, followed by centrifugation at $12000 \mathrm{x} g$ for $2 \mathrm{~min}$. Duplicate $20 \mu \mathrm{L}$ samples of the supernatant were then transferred to a 96 well plate. To measure luciferase activity, $50 \mu \mathrm{L}$ of Luciferase Assay Reagent was added to each well, and after a $2 \mathrm{~s}$ delay, luciferase activity was read for $10 \mathrm{~s}$. Luciferase activity was an indicator for AP-1 plasmid activation. Duplicate samples from the same lysate were used to measure $\beta$-gal activity with the Galacto-Light kit. First, $25 \mu \mathrm{L}$ of galacton (1:100 with reaction buffer diluent) was added to each well and the samples were incubated for 30 to $60 \mathrm{~min}$. This was then followed by the addition of $50 \mu \mathrm{L}$ of accelerator (provided in the Galacto-Light kit) to each well, and after a $2 \mathrm{~s}$ delay, $\beta$-gal activity was read for $1 \mathrm{~s}$. Luciferase and $\beta$-gal activity was measured using the FLUOstar Optima plate-reader luminometer (BMG, Fisher Scientific).

\section{Nuclear extraction and HDAC enzyme activity assay}

Since $c$-fos expression and AP-1 activity were altered within $24 \mathrm{~h}$ of treatment, it was hypothesized that cocaine would alter HDAC activity within a similar time frame. Following 24 and $36 \mathrm{~h}$ of SCT and RIT with cocaine, PC12 cells were harvested in nuclear extraction buffer A (final concentration: 10 mM HEPES; pH 7.9, $1.5 \mathrm{mM} \mathrm{MgCl}, 10 \mathrm{mM} \mathrm{KCl}, 0.5 \mu \mathrm{M}$ DTT and protease inhibitor (1 complete MINI tablet/10 mL)) containing phosphatase inhibitors ( $1 \mathrm{mM}$ each of sodium fluoride, sodium orthovanadate). Cells were lysed using a 27.5 gauge needle, and the nuclei were pelleted by centrifugation at $14000 \times g$ for $5 \mathrm{~min}$ at $4^{\circ} \mathrm{C}$. The supernatant was discarded and the pellet was rinsed in buffer A. Cells were again centrifuged at $14000 \times \mathrm{g}$ for $5 \mathrm{~min}$ at $4^{\circ} \mathrm{C}$, the supernatant discarded and the pellet re-suspended in nuclear extraction buffer B (final concentration: $20 \mathrm{mM}$ HEPES; pH 7.9, $1.5 \mathrm{mM} \mathrm{MgCl}, 420 \mathrm{mM} \mathrm{KCl}, 0.5 \mu \mathrm{M}$ DTT, $25 \%$ glycerol, $2 \mathrm{mM}$ EDTA, $1 \mathrm{mM}$ each of sodium fluoride, sodium orthovanadate, and protease inhibitor (1 complete MINI tablet/10 mL)) and kept on ice for 15 min. Following the addition of nuclear extraction buffer C (final concentration: $20 \mathrm{mM}$ HEPES; $\mathrm{pH}$ 7.9, $0.5 \mu \mathrm{M}$ DTT, $25 \%$ glycerol, $0.2 \mathrm{mM}$ EDTA, $1 \mathrm{mM}$ each of sodium fluoride, sodium orthovanadate, and protease inhibitor (1 complete MINI tablet/10 mL)), samples were centrifuged at $10000 \mathrm{x} g$ for $5 \mathrm{~min}$. The nuclear fraction in the supernatant was quantified using the method of Bradford [64].

Samples were used to detect HDAC enzyme activity using an HDAC assay kit according to the manufacturer's recommendations. Briefly, nuclear extracts $(7 \mu \mathrm{g})$ were added to a 96-well half-volume black plate, mixed with HDAC assay buffer and HDAC substrate (final concentration: $100 \mu \mathrm{M}$ ), and incubated at $37^{\circ} \mathrm{C}$ for $50 \mathrm{~min}$. 
Following incubation, HDAC reactions were halted using HDAC developer (containing $2 \mu \mathrm{M}$ Trichostatin A, final concentration: $1 \mu \mathrm{M}$ ) and incubated at room temperature for 12 to15 min. Fluorescence was detected using the FLUOstar Optima plate reader with an excitation wavelength at $350 \mathrm{~nm}$ and an emission wavelength at $460 \mathrm{~nm}$.

\section{Data Analysis \& Statistics}

For western blot analysis, each band was analyzed densitometrically as described previously $[52,65]$. To account for variability between blots, the densitometric value for each individual MOR band was expressed as a fraction of the total amount of MOR protein present on the entire blot (ie. sample MOR density/sum of density of all MOR bands on blot). The same analysis was carried out for $\alpha$-tubulin and then MOR protein values were normalized to $\alpha$-tubulin values from the same sample.

For qPCR analysis, relative mRNA levels were determined using the delta-deltaCt method of analysis. A threshold cycle $\left(\mathrm{C}_{\mathrm{T}}\right)$ was determined for each data point. A ratio was then determined for each sample using by the following formula:

$$
\text { Ratio }=2^{-[\mathrm{CT}(\mathrm{GENE})-\mathrm{CT}(\beta 2 \mathrm{M})]}
$$

where $C_{T(G E N E)}$ was the gene of interest, and $C_{T(\beta 2 M)}$ was the $C_{T}$ for $\beta$-2-microglobulin. Each data point was then expressed relative to the control sample.

In order to determine HDAC enzyme activity, a standard curve was prepared using known HDAC assay standard dilutions. The amount of fluorescence recorded was then extrapolated to the pM amount of product formed (PF) from the standard curve. The specific activity $(\mathrm{SpA})$ in $\mathrm{pM} / \mathrm{min} / \mathrm{mg}$ was then determined using the $\mathrm{PF}$, incubation time in min (IT), and mass of nuclear extract in $\mathrm{mg}(\mathrm{mnx})$, by using the following formula:

$$
\mathrm{SpA}=(\mathrm{PF} / \mathrm{IT}) / \mathrm{mnx}
$$

To determine relative luciferase activity, each sample was expressed as a percentage of the total amount of luciferase activity detected for each sample set. Luciferase activity was then normalized to $\beta$-gal activity within the same sample.

Data are representative of 5 independent experiments (except where otherwise indicated) and are presented as the mean \pm standard error of the mean (SEM). Data were assessed for normality and homogeneity of variance and statistical analysis was carried out using a one or two-way analysis of variance (ANOVA). In the case of a one-way ANOVA, analysis was followed by Dunnett's test or the Tukey-Kramer Multiple Comparisons test to determine which groups were significantly different. One-way ANOVA analysis was carried out for protein and RNA analysis of MOR levels following cocaine treatment, or for experiments with L-NAME pretreatment. For RNA analysis with cocaine and L-NAME, the data did not pass the Bartlett test for homogeneity of variance, therefore a Kruskal-Wallis non-parametric ANOVA was performed. For two-way ANOVA with interaction, analysis was followed by Bonferroni's multiple comparisons t-test to determine which groups were significantly different. This analysis was used to determine significant changes in MOR protein expression following cocaine and curcumin treatments, and used to determine significant changes in $c$-fos mRNA expression following cocaine treatments over time. For two-way ANOVA without interaction, analysis was followed by contrast analysis to determine which groups were significantly different, and was used to determine significant changes in histone deacetylase activity following cocaine administration. Mean values were considered different if $\mathrm{p}<0.05$.

For the protein half-life and AP-1 experiments, following western blot and luciferase analysis as described above, data were assessed for normality and homogeneity of variance. Due to a large disparity between variances, the natural log was taken for each data point. For the AP-1 luciferase analysis experiment, statistical analysis was carried out using a one-way ANOVA. Following transformation in the protein half-life experiment, data were analyzed using an analysis of co-variance (ANCOVA) to determine the effect of each treatment, as well as significant differences that may exist between the slopes of the resulting regression lines. The original raw data was also used to perform an ANCOVA, and, where possible, the resulting regression line was used to determine an approximate MOR half-life for each treatment. Mean values were considered different if $\mathrm{p}<0.05$.

Data analysis was carried out using GraphPad InStat for one way ANOVA analysis, GraphPad Prism 4.0 or SAS 9.2 (SAS Institute, Cary, NC) for two-way ANOVA analysis with interaction, and SAS 9.2 for two-way ANOVA analysis without interaction, as well as ANCOVA analysis.

\section{Results}

\section{Cocaine modulates MOR protein and mRNA levels, and protein half-life}

The effect of cocaine on MOR protein levels was evaluated in extracts of control and treated (see Table 1 for treatment details) PC12 cells using western blot analysis. Figure 1A displays a representative immunoblot of MOR levels (upper panel) and corresponding $\alpha$-tubulin levels (lower panel) obtained from cells treated with SCT or RIT with 10,100 or $500 \mu \mathrm{M}$ cocaine for $72 \mathrm{~h}$. Densitometric analysis (Figure 1B) revealed a significant increase in MOR protein levels $[\mathrm{F}(6,33)=5.75]$ relative to control in cells exposed to $500 \mu \mathrm{M} S C T(\mathrm{p}<0.05)$ or $100 \mu \mathrm{M} R I T$ 
Table 1 Cocaine treatment regimens

\begin{tabular}{ll}
\hline Regimen & Description \\
\hline SCT & $\begin{array}{l}\text { A single dose of cocaine added to the cell culture media } \\
\text { and not removed over the entire time-course }\end{array}$ \\
RIT & $\begin{array}{l}\text { Three daily intermittent } 30 \text { min treatments applied to the } \\
\text { cells separated by } 1 \mathrm{~h} \text { of regular cell culture media. }\end{array}$ \\
\hline
\end{tabular}

PC12 cells were either given a single continuous treatment (SCT) or a repeated intermittent treatment (RIT) of cocaine.

$(\mathrm{p}<0.01)$ cocaine. These treatments did not compromise PC12 cell viability: metabolic activity assessed with the MTT reduction assay indicated that, relative to control, there was only a modest decrease in activity in cocainetreated cells $(100 \mu \mathrm{M}$ RIT: $90.1 \pm 4.2 \%$ of control, $\mathrm{n}=4$; $500 \mu$ M SCT: $93.4 \pm 2.9 \%$ of control, $n=4)$, which was not statistically significant. On the basis of these data,
$500 \mu \mathrm{M} S C T$ and $100 \mu \mathrm{M}$ RIT cocaine were used in subsequent experiments.

To determine whether the cocaine-induced increase in MOR protein level was due to an increase in protein stability, protein extracts were obtained from cells treated for $72 \mathrm{~h}$ with $500 \mu \mathrm{M} S C T$ or $100 \mu \mathrm{M}$ RIT cocaine followed by $10 \mu \mathrm{g} / \mathrm{mL}$ cycloheximide for $4,8,12,24$ or $48 \mathrm{~h}$. Densitometric analysis of MOR protein levels relative to $\alpha$-tubulin revealed an estimated MOR half-life of $36.3 \mathrm{~h}$ in control (untreated) cells (Figure 1C), and a statistically significant effect of cocaine $[\mathrm{F}(2,103)=13.94, \mathrm{p}<0.0001]$ and time $(\mathrm{h})[\mathrm{F}(1,103)=17.11, \mathrm{p}<0.0001]$. Both treatment regimens significantly changed the slope of protein decay compared to control, indicating that cocaine increased MOR half-life. Although it was not possible to calculate a predicted half-life for the cells treated
A
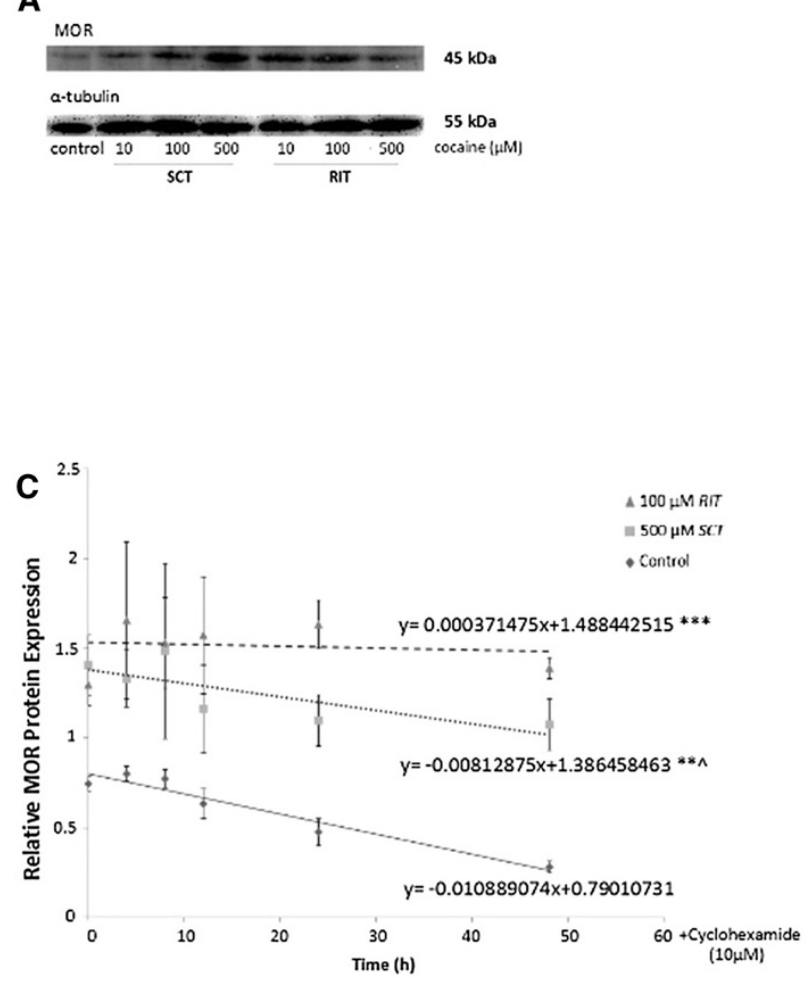

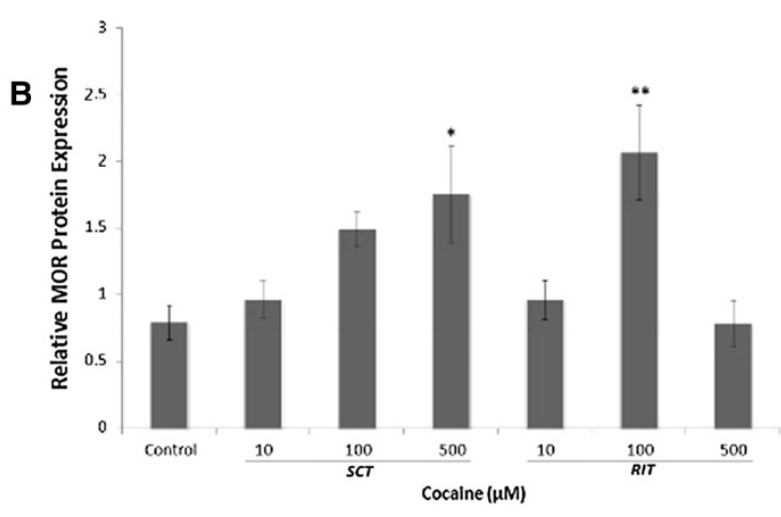

D $\quad{ }^{180}$

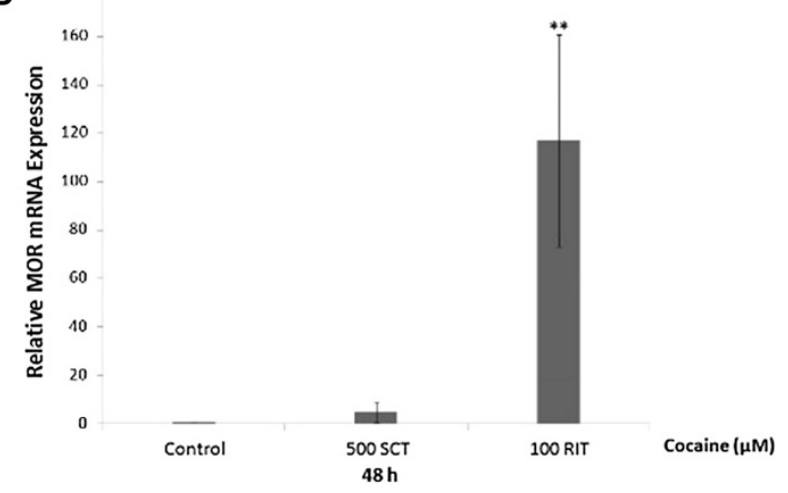

Figure 1 Effect of cocaine on MOR protein and mRNA expression in PC12 cells. (A) Representative immunoblots obtained from lysates of control (untreated) and continuous (SCT) or intermittent (RIT) 10, 100, $500 \mu \mathrm{M}$ cocaine treated PC12 cells separated by SDS-PAGE and transferred to nitrocellulose membranes. The top panel represents total MOR expression and the bottom panel shows a-tubulin levels from the same blot. (B) Densitometric analysis of MOR protein levels relative to a-tubulin levels in cocaine-treated cells revealed a significant increase in MOR expression following $500 \mu \mathrm{M}$ SCT or $100 \mu \mathrm{M}$ RIT compared to control. (C) Cell lysates were obtained from cells exposed to $500 \mu \mathrm{M}$ SCT or $100 \mu \mathrm{M}$ RIT with cocaine for $72 \mathrm{~h}$, followed by $10 \mu \mathrm{g} / \mathrm{mL}$ cycloheximide for 4, 8, 12, 24 and $48 \mathrm{~h}$. Densitometric analysis of MOR protein expression normalized to a-tubulin revealed an approximate half-life of $36.3 \mathrm{~h}$ in control (untreated) cells, and a significant change in the slope of protein decay following both cocaine treatment regimens. Protein half-life could not be estimated for RIT, but an increase in the predicted half-life to $85.3 \mathrm{~h}$ was calculated for SCT. (D) Quantitative PCR (qPCR) analysis of MOR mRNA levels relative to $\beta-2$ microglobulin in control and cocaine treated cells. Relative to control, $100 \mu \mathrm{M}$ of RIT with cocaine significantly increased MOR mRNA levels while $500 \mu \mathrm{M}$ of SCT had no effect. Results are representative of at least 5 independent experiments and the data are presented as mean \pm SEM $\left({ }^{*} p<0.05,{ }^{* *} p<0.01,{ }^{* * *} p<0.001\right.$, $\left.{ }^{* *} \wedge p=0.001\right)$. 
with $100 \mu \mathrm{M}$ RIT cocaine, MOR protein half-life following exposure to $500 \mu \mathrm{M} \mathrm{SCT}$ was estimated to be $85.3 \mathrm{~h}$.

The effect of cocaine on MOR mRNA levels was also examined (Figure 1D). RNA was isolated from cells treated for $48 \mathrm{~h}$ with either $500 \mu \mathrm{M} S C T$ or $100 \mu \mathrm{M}$ RIT cocaine and levels of MOR mRNA relative to $\beta 2$-microglobulin were assessed by reverse transcriptase (RT)-real time PCR (qPCR) analysis. Compared to control, a statistically significant increase in relative MOR mRNA levels was detected in cocaine-treated cells following $\operatorname{RIT}[\mathrm{F}(2,15)=$ 6.80, $\mathrm{p}<0.01]$, but not $S C T$.

\section{Effect of cocaine on nitric oxide, and its role in MOR protein and mRNA expression}

To examine the effect of cocaine on NO production, PC12 cells were treated with $500 \mu \mathrm{M} S C T$ or $100 \mu \mathrm{M}$ RIT for $72 \mathrm{~h}$ and diaminofluorescein-2 (DAF-2) fluorescence was examined. A low level of DAF-2 fluorescence, indicative of NO production, was observed in untreated $\mathrm{PC} 12$ cells (Figure 2A). DAF-2 fluorescence was increased in cocaine-treated cells with both treatments, and this increase was prevented when cells were pretreated with the non-selective NOS inhibitor L-NAME (20 mM).

In the subsequent experiment, $\mathrm{PC} 12$ cells were treated with $20 \mathrm{mM}$ of L-NAME prior to $500 \mu \mathrm{M} S C T$ or $100 \mu \mathrm{M}$ RIT cocaine. Representative western blots depicting MOR and $\alpha$-tubulin levels in extracts obtained from cells treated with cocaine in the presence or absence of L-NAME are presented in Figure 2B, and densitometric analysis of MOR expression relative to $\alpha$-tubulin is depicted in Figure 2C. Relative to control, a significant increase in MOR protein levels was observed in cells treated for $72 \mathrm{~h}$ with either $500 \mu \mathrm{M} S C T$ or $100 \mu \mathrm{M}$ RIT cocaine $[\mathrm{F}(5,26)=$ 3.43, $\mathrm{p}<0.05$ for both treatments]. This increase was not observed in cells pretreated with L-NAME.

The final experiment assessed the effect of $20 \mathrm{mM}$ L-NAME pretreatment on MOR mRNA levels increased following $100 \mu \mathrm{M} \mathrm{RIT}$ cocaine. Compared to control, qPCR analysis (Figure 2D) revealed that cocaine significantly increased relative MOR mRNA levels (KruskalWallis statistic $=15.36, \mathrm{p}<0.001)$, and that this was prevented by pretreatment with L-NAME.

\section{Effect of cocaine on c-fos mRNA levels and AP-1 binding}

Qualitative assessment of $c$-fos levels in PC12 cells treated with $100 \mu \mathrm{M}$ RIT cocaine for $0.5,1$ or $2 \mathrm{~h}$, revealed increases in steady-state $c$-fos mRNA (Figure 3A) relative to control. This was confirmed by qPCR analysis (Figure $3 \mathrm{~B}$ ) which revealed cocaine significantly increased relative $c$-fos mRNA levels $[\mathrm{F}(1,21)=11.41, \mathrm{p}<0.01]$. No increase in $c$-fos was detected following SCT cocaine. To investigate the effect of cocaine on AP-1 activity, PC12 cells were transiently transfected with a plasmid containing 7 AP-1 binding elements upstream from a luciferase reporter gene. The day after transfection, cells were exposed to 10,100 or $500 \mu \mathrm{M} S C T$ or RIT cocaine and harvested $6 \mathrm{~h}$ after the start of treatment (Figure 3C). As a positive control, other cells were treated with $50 \mathrm{ng} / \mathrm{mL}$ nerve growth factor (NGF) for $6 \mathrm{~h}$ [51]. Although modest compared to the NGF-mediated increase in AP-1 activity, both 10 and $100 \mu \mathrm{M}$ RIT cocaine significantly increased AP-1 activity compared to control $[F(7,33)=10.181$, $\mathrm{p}<0.01$ for NGF, $\mathrm{p}<0.05$ for cocaine]. No increase in luciferase activity was detected following $S C T$ at all of the doses tested.

\section{Effect of cocaine on HDACs, and the role of histone acetylation in MOR protein expression}

PC12 cells were treated with $500 \mu \mathrm{M} S C T$ or $100 \mu \mathrm{M}$ RIT cocaine, and HDACs activity in nuclear extracts was evaluated 24 or $36 \mathrm{~h}$ after treatment (Figure 4A). Following both time points and treatments, HDACs activity was significantly inhibited in comparison to control $[\mathrm{F}(2,29)=3.43, \mathrm{p}<0.05]$. There was no difference in the level of HDAC inhibition between either treatment conditions or treatment times.

In a subsequent experiment, $\mathrm{PC} 12$ cells were treated with 1,3 or $5 \mu \mathrm{M}$ curcumin, a non-selective HAT inhibitor, for $1 \mathrm{~h}$ prior to exposure to either $500 \mu \mathrm{M} S C T$ or $100 \mu \mathrm{M}$ RIT cocaine for $72 \mathrm{~h}$. Relative levels of MOR protein from these cell extracts was compared to those obtained from untreated cells, and those treated with the inhibitor or cocaine alone. Statistical analysis revealed an overall significant interaction between the effects of curcumin and cocaine on MOR protein expression $[F(6,52)=15.25, \mathrm{p}<0.0001]$, a significant effect of curcumin alone $[\mathrm{F}(3,52)=20.62, \mathrm{p}<0.0001]$, and a significant effect of cocaine alone $[F(2,52)=15.87$, $\mathrm{p}<0.0001]$. Pre-treatment with $3 \mu \mathrm{M}$ curcumin significantly decreased MOR expression in cells treated with $500 \mu \mathrm{M}$ SCT cocaine compared to cocaine alone $(\mathrm{p}<0.0001)$. Additionally, MOR levels in cells pre-treated with 1,3 , and $5 \mu \mathrm{M}$ curcumin followed by $100 \mu \mathrm{M}$ RIT cocaine were significantly lower than those receiving RIT cocaine alone $(\mathrm{p}<0.05$ for $1 \mu \mathrm{M}, \mathrm{p}<0.0001$ for 3 and $5 \mu \mathrm{M}$ curcumin).

\section{Discussion}

The present study identified a number of cellular mechanisms by which cocaine alters MOR expression. Treatment of PC12 cells with either a single dose or repeated doses of cocaine increased MOR protein levels. The mechanisms regulating this increase were dependent on the treatment regimen used. Both SCT and RIT increased MOR protein stability, indicating that both regimens increased MOR protein levels post-transcriptionally. RIT elevated MOR and $c$-fos mRNA levels and AP-1 activity, but a single dose of cocaine did not, indicating that multiple 


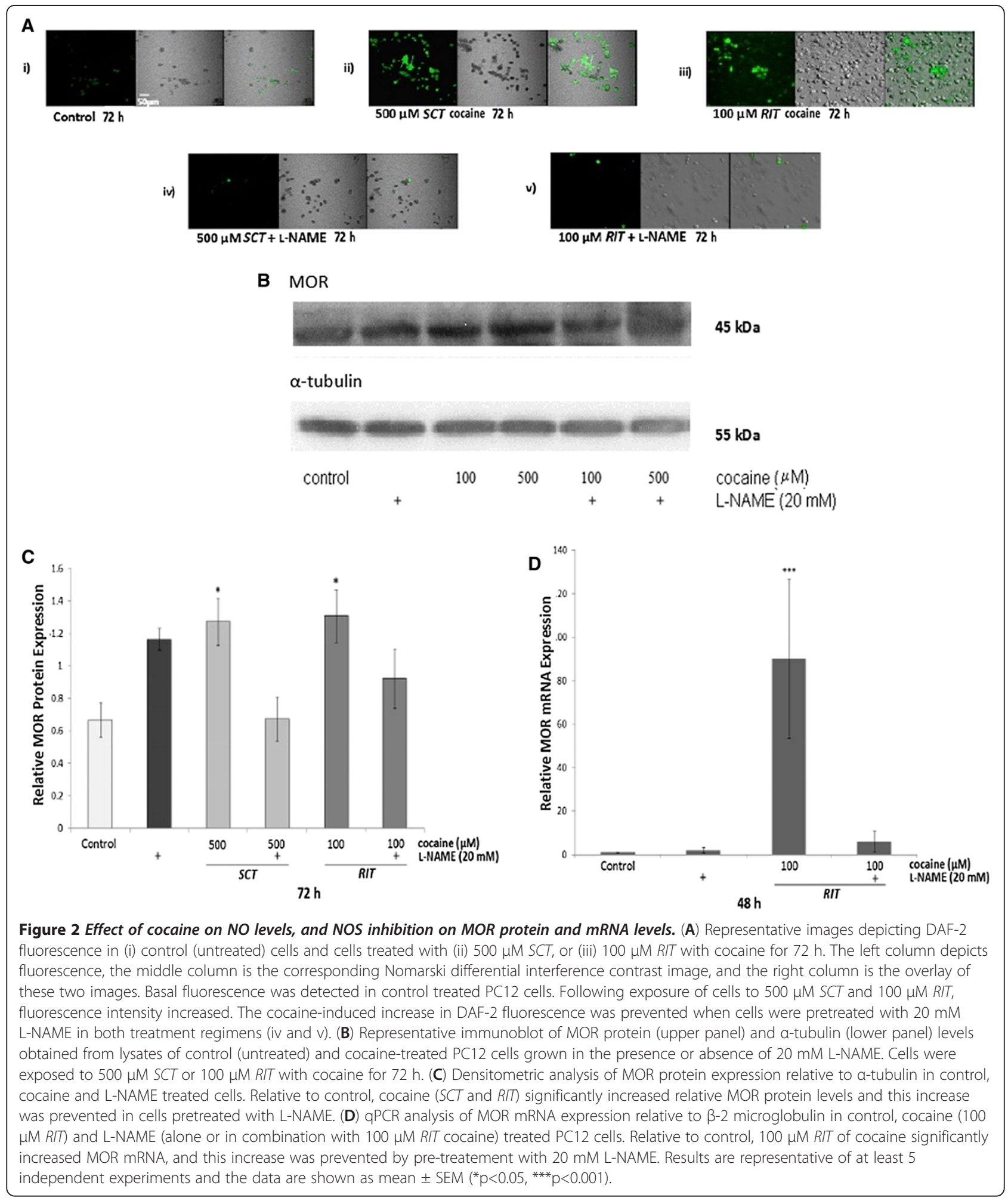

cocaine doses were required for transcriptional regulation of MOR. Both dosing regimens also increased NO production and inhibited HDACs activity. Finally, cocaine-induced increases in MOR expression were attenuated by pretreatment with the NOS inhibitor
L-NAME, and by the non-selective HAT inhibitor curcumin. Therefore, in PC12 cells, both $\mathrm{NO}$ and histone acetylation play an important role in the transcriptional and post-transcriptional regulation of MOR levels by cocaine. 

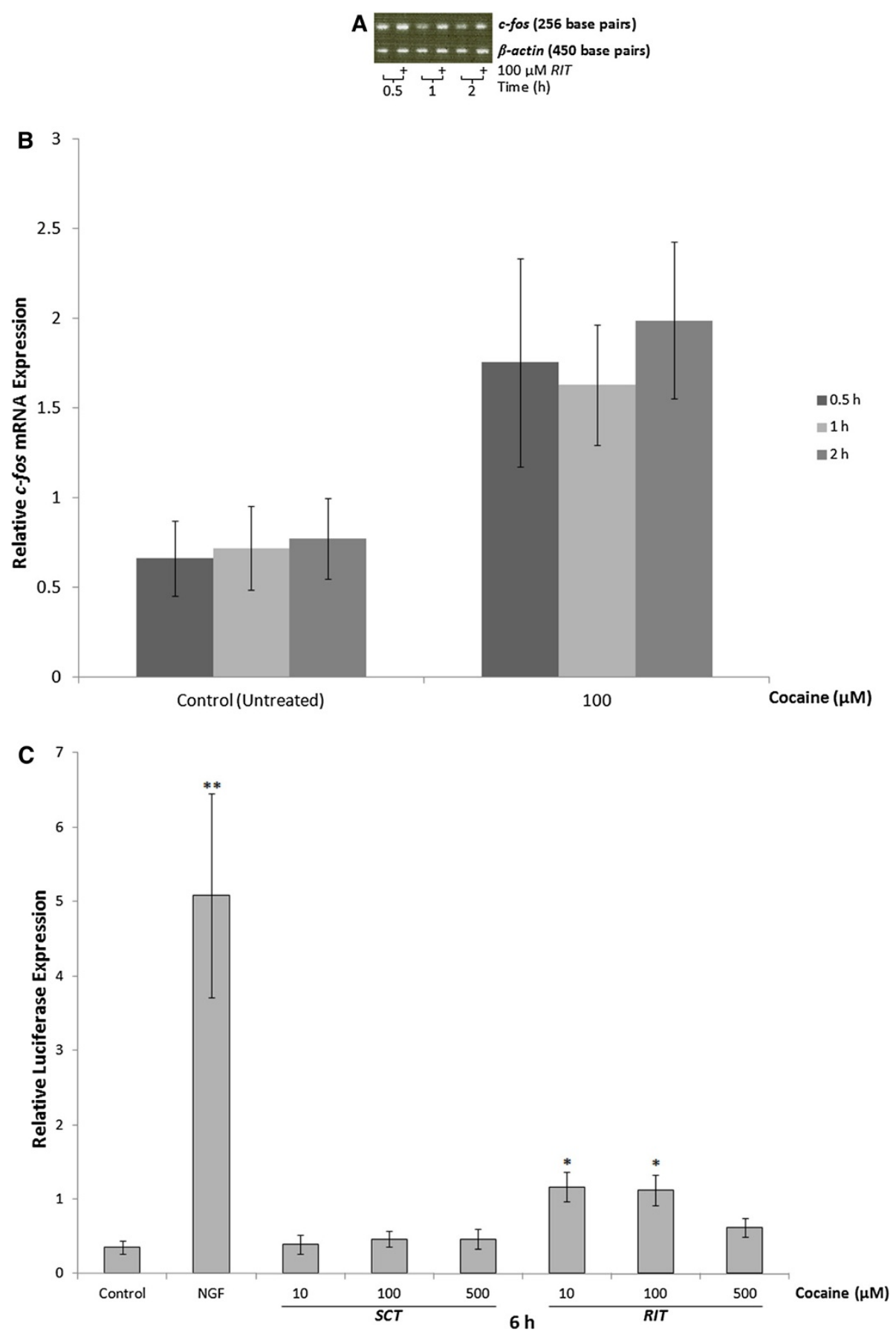

Figure 3 Effect of cocaine on c-fos mRNA levels and AP-1 activity. (A) Representative ethidium bromide-stained gel showing amplification of c-fos (upper band) and $\beta$-actin (lower band) transcripts obtained from RNA extracted from control and cocaine-treated (100 $\mu M$ RIT) PC12 cells, and harvested $0.5,1$, or $2 \mathrm{~h}$ after the last of three intermittent cocaine treatments. Qualitative assessment indicated that compared to control, cocaine exposure increased levels of $c$-fos mRNA at all of the time-points examined. (B) Quantitative PCR (qPCR) analysis of c-fos mRNA levels relative to $\beta-2$ microglobulin in control and cocaine treated cells. Relative to control, $100 \mu \mathrm{M}$ of RIT with cocaine significantly increased c-fos mRNA levels $[F(1,21)=11.41, p<0.01]$. (C) PC12 cells were transiently transfected with a luciferase-reporter plasmid containing 7 AP-1 transcription factor binding sites prior to treatment with $50 \mathrm{ng} / \mathrm{mL}$ NGF or cocaine $(10,100$, or $500 \mu \mathrm{M}$ SCT or RIT) for $6 \mathrm{~h}$. Luciferase activity in each sample was normalized to its corresponding $\beta$-gal activity. Relative to control, there was a significant increase in luciferase activity in PC12 cells treated with NGF, or 10 or $100 \mu \mathrm{M} R / T$ with cocaine. Results are representative of at least 5 independent experiments and data are presented as the mean \pm SEM $\left({ }^{*} p<0.05,{ }^{* *} p<0.01\right)$. 

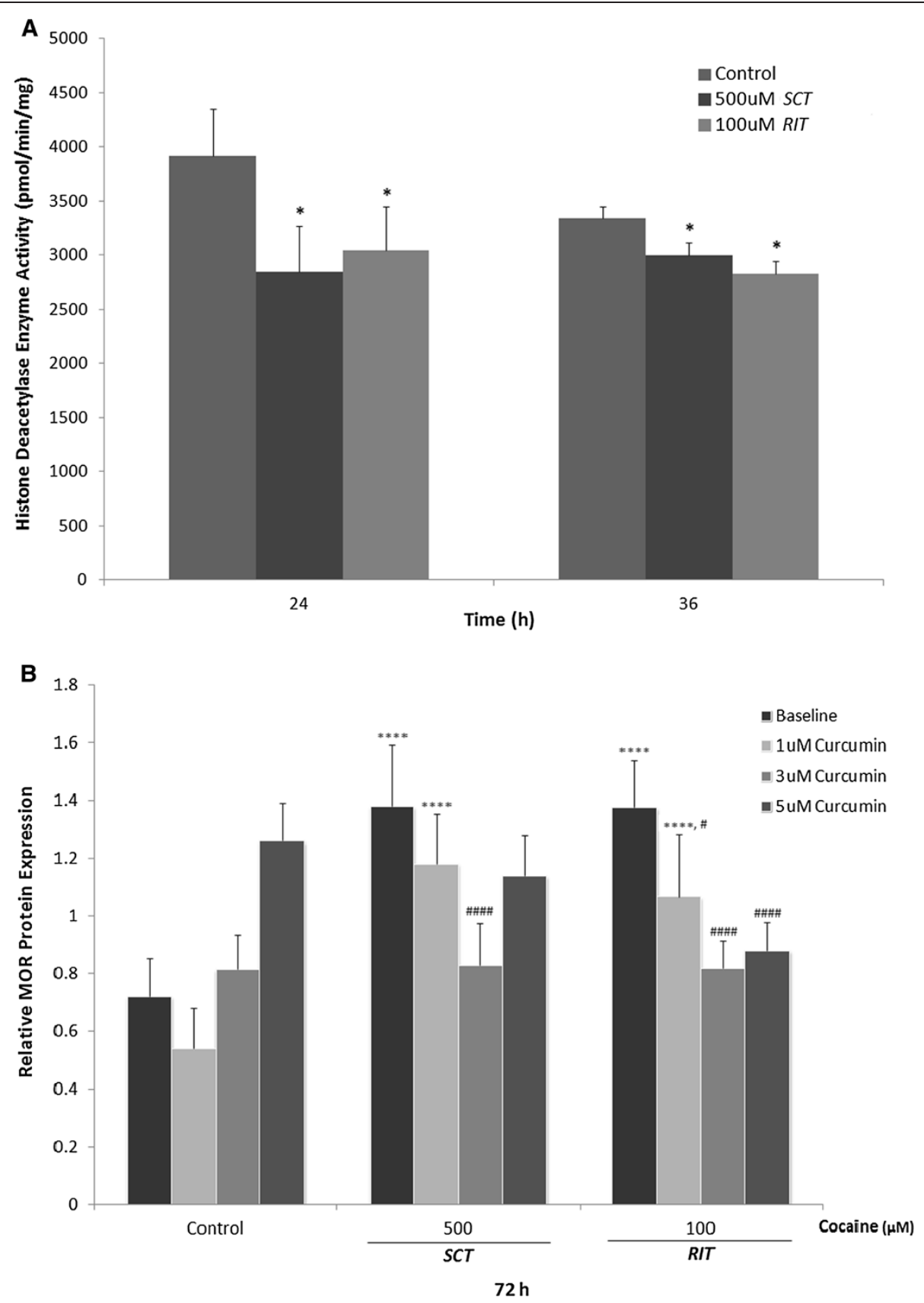

Figure 4 Effect of cocaine on HDAC activity, and inhibition of HAT on cocaine-induced MOR protein levels. (A) Nuclear extracts were obtained from lysates of PC12 cells treated with cocaine (500 $\mu \mathrm{M}$ SCT or $100 \mu \mathrm{M}$ RIT) for 24 or 36 hours. HDAC enzyme activity was determined using a fluorescent microplate reader and expressed as specific activity, in $\mathrm{pM} / \mathrm{min} / \mathrm{mg}$. Statistical analysis revealed a significant decrease in HDAC activity following both cocaine treatment regimens at both 24 and $36 \mathrm{~h}$. (B) Densitometric analysis of MOR protein levels relative to a-tubulin in control and $72 \mathrm{~h}$ cocaine $(100 \mu \mathrm{M}$ SCT and $500 \mu \mathrm{M}$ R/T) treated cells grown in the presence and absence of 1, 3 or $5 \mu \mathrm{M}$ curcumin. Compared to control, both SCT and RIT with cocaine increased MOR protein levels. For SCT, there was a significant decrease in MOR expression after pretreatment with $3 \mu \mathrm{M}$ curcumin compared to cells treated with cocaine alone. Pre-treatment with 1, 3 and $5 \mu \mathrm{M}$ curcumin also prevented the increase in relative MOR protein levels resulting from $100 \mu \mathrm{M} R I T$. Results are representative of at least 5 independent experiments and data are presented as mean \pm SEM $\left({ }^{*} p<0.05,{ }^{* * *} p<0.0001\right.$ compared to control, \#p<0.05, \#\#\#p<0.0001 compared to cocaine alone).

Cocaine has been reported to increase MOR mRNA levels and receptor density in several regions of the rat brain $[6,7,66]$. In the PC12 cellular model, both repeated doses and a single dose of cocaine increased MOR protein levels, but only repeated doses elevated MOR mRNA levels. This suggests that different treatment regimens regulate MOR expression through different mechanisms, and that multiple doses of cocaine are 
necessary for transcriptional regulation of the MOR. To investigate this possibility further, the effect of RIT and $S C T$ cocaine on potential transcriptional regulators of MOR expression, $c$-fos expression and AP-1 activity, was also assessed.

Several studies have demonstrated increases in c-Fos levels following cocaine administration [27,30,31,40,67]. c-Fos binds to members of the Jun immediate early gene family to form the AP-1 transcription factor $[68,69]$. Since the promoter of the MOR gene contains consensus sequences for binding $\mathrm{AP}-1$ transcription factors [33], AP-1 activity was assessed in PC12 cells treated with cocaine. It was found that the effect of cocaine on AP-1 activity was dependent on the treatment regimen. In fact, only exposure to multiple cocaine doses increased c-fos mRNA levels and AP-1 activity, suggesting that increased MOP-r mRNA levels induced by $100 \mathrm{uM}$ RIT in PC12 cells could be mediated by AP-1. Increased $c$-fos expression following repeated in vivo cocaine administration has been linked to cocaineinduced phosphorylation of CREB [70]. Since CREB is an important regulator of $c$-fos transcription (reviewed in [71]), it is possible the increased c-fos mRNA levels observed following RIT in the present study are the result of cocaine-induced CREB phosphorylation. Although we only focused on one potential candidate, other transcription factors, such as SP-1 and NF- $\mathrm{kB}$ are also increased in PC12 cells following cocaine administration. [72,73] and activation of these transcription factors has been linked to increases in MOR transcription and mRNA expression [74-76]).

The present study also investigated the role of $\mathrm{NO}$ in regulating cocaine-induced changes in MOR protein levels. NO has been found to contribute to the behavioral effects of cocaine, including conditioned place preference and sensitization [77-83]. In addition, $\mathrm{NO}$ has been reported to modulate CREB phosphorylation and DNA binding [84,85], increase the expression of immediate early genes such as c-Fos and Jun-B [25,28,29] and increase transcription from AP-1 responsive promoters $[25,29]$, suggesting that NO could also be involved in regulating MOR transcription. In PC12 cells, pretreatment with the NOS inhibitor L-NAME prevented cocaine-induced up-regulation of MOR mRNA and protein. Additionally, NO production was assessed visually by loading the cells with DAF-2DA as described previously [53]. Both $100 \mu \mathrm{M}$ RIT and $500 \mu \mathrm{M}$ SCT cocaine substantially enhanced DAF-2 fluorescence relative to control (untreated) cells indicating both dosing regimens result in increased NO production. This cocaine-mediated increase in DAF-2 fluorescence was blocked by pre-treated with 20 mM L-NAME, the dose of L-NAME that also prevented cocaine-induced increases in MOR protein and mRNA levels. Taken together, these findings indicate that NO modulates cocaine-induced changes in MOR protein levels. Interestingly, in in vivo neuronal models, cocaine increases NO production by increasing neuronal NOS (nNOS) protein levels and activation [22,23,78,79] via dopamine-, glutamate- and MOR-dependent mechanisms $[22,23,79]$. Because the PC12 cell culture model does not contain these pre- and post-synaptic systems, the current findings support the intriguing possibility that cocaine can alter NO levels and/or activity by direct intracellular actions. The specific target of these direct actions, and its biological significance, will require further investigation.

These experiments in PC12 cells identified another possible mechanism through which cocaine could increase MOR expression. NO has been reported to decrease HDACs activity [34,35], enzymes that are linked to the behavioral effects of cocaine in rats [36,37], and inhibition of these enzymes prolongs histone acetylation and contributes to enhanced transcription [43-47]. In the present study, both RIT and SCT cocaine decreased HDACs activity indicating that in vitro cocaine exposure enhances histone acetylation. In addition, pre-treatment with the non-selective HAT inhibitor curcumin prevented the cocaine-induced up-regulation of MOR protein levels for both dosing regimens. In vivo studies in rats have demonstrated that cocaine increases histone acetylation [36,86,87]. Our findings complement and extend these findings, and suggest that cocaine-mediated alterations in histone acetylation could be an important regulator of MOR protein levels. However, additional actions of curcumin could also contribute to these effects. In fact, cocaine induces the expression of cytokines, such as interleukin-1 $\beta$ [88] which can also regulate MOR transcription [89]. Curcumin inhibits interleukin$1 \beta$-induced NF- $\mathrm{BB}$ activation [90], suggesting the possibility that the anti-inflammatory properties of curcumin could contribute to its ability to inhibit MOR transcription.

The relationship between $\mathrm{NO}$ and HDACs is also complex. Although the cocaine-induced increase in $\mathrm{NO}$ observed in the present study could be responsible for decreasing HDACs activity, inhibition of HDACs has also been associated with increases in eNOS mRNA [91]. Increased constitutive NOS levels and increases in $\mathrm{NO}$ production resulting in S-nitrosylation have been reported to regulate protein stability $[43,44,47]$. Thus, in the PC12 cell model, NO and HDACs could modulate MOR expression independently, or may regulate each other to affect MOR transcription and protein stability. As well, the cocaine-induced increase in c-fos expression and AP-1 activity, only observed after RIT, together with increased histone acetylation could be involved in the transcriptional regulation of MOR. Interestingly, both cocaine and NO were reported to increase $c$-fos expression in vivo [92], and increases in $c$-fos are correlated 
with hyperacetylation of $\mathrm{H} 3$ histones during chronic cocaine administration and $\mathrm{H} 4$ histones after a single acute dose [93], suggesting that similar cellular mechanisms could be regulating the effects of cocaine in vitro and in vivo.

Although we identified NO and histone acetylation as important regulators of cocaine-induced MOR protein expression, how cocaine initiated the observed effects remains unclear. Blockade of sodium channels following passive entry of cocaine into PC12 cells is one possibility. However, this may not be the only mechanism because, in PC12 cells, NO activity is associated with extracellular signal-regulated kinase (ERK) pathway activation [94-97], and Tan et al. [98] found that the selective sodium channel inhibitor tetrodotoxin had no effect on this pathway. We determined previously that $\mathrm{NO}$ modulates ERK activity in PC12 cells [54], and since blockade of ERK phosphorylation in the nucleus accumbens of rats inhibits cocaine-induced behavioural sensitization [99], it is possible that in our system NOmediated activation of ERK contributes to cocaineinduced MOR expression. In vivo cocaine exposure increases dopamine accumulation, through inhibition of dopamine reuptake by the dopamine transporter (for reviews, see: $[14,100])$, and the dopamine transporter inhibitor sydnocarb has been shown to increase NO generation [101]. Interestingly, Imam et al. [56] reported that cocaine, increased $\mathrm{NF}_{\mathrm{K} B}$ expression, and dose-dependently decreased both dopamine transporter expression and intracellular dopamine concentrations in differentiated PC12 cells. Elevations in extracellular dopamine could result in dopamine receptor activation, and inhibition of the D1 sub-type of dopamine receptor was reported to partially inhibit cocaine-induced increase in NF-kB [73]. Because NF-kB has also been implicated in regulating NOS expression and NO production [102,103], indirect activation of the D1 receptor by cocaine could enhance NO production. Whether the increases in NO observed in the current study resulted from cocaine-induced dopamine accumulation and dopamine receptor activation requires further investigation. Finally, cocaine has also been reported to diffuse through the membrane of cells [104], suggesting that it may exert direct effects on gene or protein expression.

There are several advantages to identify cellular mechanisms in cell lines, however some limitations of this system need to be considered. In contrast to neurons, PC12 cells continue to divide, and this could make

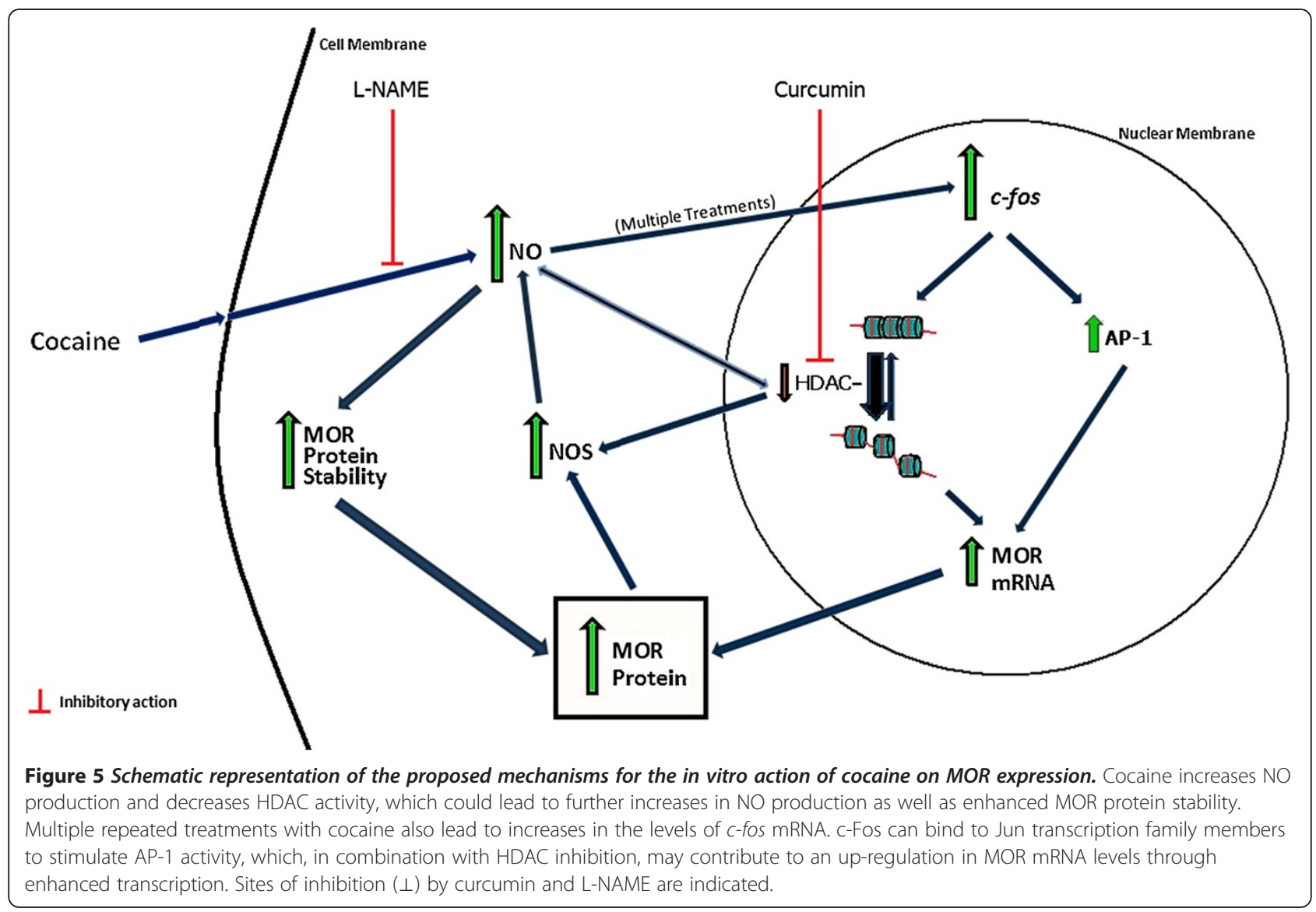


them less vulnerable to neurotoxic compounds. Although we have identified many similarities between our findings and previous in vivo studies, differences in the biology of cocaine in the intact organisms compared to the effects observed in vitro are likely to exist. The physiological relevance of the doses and regimens employed in these in vitro studies is also not known. The doses selected for the present study were based on a previous study that characterized changes in protooncogene expression in differentiated PC12 cells [56]. It is not known whether similar treatment regimens, or doses of cocaine, would exert similar effects in an in vitro neuronal model or in vivo. Further the authors are not aware of any study that has established concentrations of cocaine in the extracellular fluid required to initiate changes in NO production or epigenetic modifications in neurons, or whether cocaine can act on these mechanisms by pathways that do not involve the transporters of catecholamines. Therefore, the current results in the PC12 cell model are important as they propose testable hypotheses about cellular and molecular mechanisms through which cocaine modulates MOR protein and gene expression in neurons.

\section{Conclusions}

The data presented in this study support a model in which cocaine enhances MOR protein expression by increasing cellular NO levels and by decreasing HDAC activity (Figure 5). In addition to cocaine activating these effects independently, elevations in NO could also alter HDAC activity. Inhibition of HDACs could further enhance NO production, resulting in increased MOR expression and protein stability. Additionally, increases in $c$-fos (following multiple treatments) may lead to a modest increase in AP-1 activity that, in combination with enhanced histone acetylation, could contribute to the up-regulation of MOR transcription. Whether these mechanisms occur in neurons, and whether they have implications for the behavioral effects of cocaine, should be the focus of additional investigations.

\section{Abbreviations \\ ANOVA: analysis of variance; ANCOVA: analysis of co-variance; AP-1: activator protein 1; DAF-2 DA: 4,5-diaminofluorescein diacetate; HAT: histone acetyltransferase; HDAC: histone deacetylase; L-NAME: $\mathrm{N}^{\omega}$-nitro-L-arginine methyl ester; MOR: $\mu$-opioid receptor; nNOS: neuronal nitric oxide synthase; RIPA: radioimmunoprecipitation assay; SEM: standard error of the mean; TBS-T: TBS containing $0.1 \%$ tween 20.}

\section{Competing interests}

The authors declare that they have no competing interests.

\section{Authors' contributions}

WW carried out all of the above experiments, performed the statistical analysis and contributed to the preparation of the manuscript. FL participated in the experimental design of the study, provided some of the materials used, and edited the manuscript. BK supervised the experiments, provided the laboratory facilities and the majority of the reagents used in the study, and contributed to the preparation of the manuscript. All authors participated equally in the conception of the study, the interpretation of the data and have read and approved the final manuscript.

\section{Acknowledgements}

We wish to thank Mrs. Jennifer Winick-Ng for her help and expertise in the statistical analysis of this study, as well as Dr. Neil MacLusky for his careful review and editing of the manuscript. This work was supported by operating grants from the Natural Sciences and Engineering Research Council of Canada (NSERC) to BK and FL.

\section{Author details}

${ }^{1}$ Department of Biomedical Sciences, University of Guelph, Guelph, Ontario N1G 2W1, Canada. '2Department of Psychology, University of Guelph, Guelph, Ontario N1G 2W1, Canada.

Received: 23 April 2012 Accepted: 11 October 2012

Published: 18 October 2012

\section{References}

1. Cummins E, Leri F: Animal studies trigger new insights on the use of methadone maintenance. Exp Opin Drug Disc 2009, 4:577.

2. Kreek MJ, Zhou Y, Butelman ER, Levran O: Opiate and cocaine addiction: from bench to clinic and back to the bench. Curr Opin Pharmacol 2009, 9:74-80.

3. Roth-Deri I, Green-Sadan T, Yadid G: Beta-endorphin and drug-induced reward and reinforcement. Prog Neurobiol 2008, 86:1-21.

4. Shippenberg TS, Zapata A, Chefer VI: Dynorphin and the pathophysiology of drug addiction. Pharmacol 2007, 116:306-321.

5. Wee S, Koob GF: The role of the dynorphin-kappa opioid system in the reinforcing effects of drugs of abuse. Psychopharmacology (Berl) 2010, 210:121-135.

6. Azaryan AV, Clock BJ, Cox BM: Mu opioid receptor mRNA in nucleus accumbens is elevated following dopamine receptor activation. Neurochem Res 1996, 21:1411-1415.

7. Bailey A, Yuferov V, Bendor J, Schlussman SD, Zhou Y, Ho A, Kreek MJ: Immediate withdrawal from chronic "binge" cocaine administration increases mu-opioid receptor mRNA levels in rat frontal cortex. Brain Res Mol Brain Res 2005, 137:258-262.

8. Cohen BM, Nguyen TV, Hyman SE: Cocaine-induced changes in gene expression in rat brain. NIDA Res Monogr 1991, 105:175-181.

9. Unterwald EM: Regulation of opioid receptors by cocaine. Ann N Y Acad Sci 2001, 937:74-92.

10. Zhou Y, Spangler R, Schlussman SD, Yuferov VP, Sora I, Ho A, Uhl GR, Kreek MJ: Effects of acute "binge" cocaine on preprodynorphin, preproenkephalin, proopiomelanocortin, and corticotropin-releasing hormone receptor mRNA levels in the striatum and hypothalamicpituitary-adrenal axis of mu-opioid receptor knockout mice. Synapse 2002, 45:220-229.

11. Zhou Y, Proudnikov D, Yuferov V, Kreek MJ: Drug-induced and genetic alterations in stress-responsive systems: Implications for specific addictive diseases. Brain Res 2010, 1314:235-252.

12. Di Chiara G: The role of dopamine in drug abuse viewed from the perspective of its role in motivation. Drug Alcohol Depend 1995, 38:95-137.

13. Koob G, Kreek MJ: Stress, dysregulation of drug reward pathways, and the transition to drug dependence. Am J Psychiatry 2007, 164:1149-1159.

14. Wise RA: Neurobiology of addiction. Curr Opin Neurobiol 1996, 6:243-251.

15. Leri F, Zhou Y, Goddard B, Cummins E, Kreek MJ: Effects of high-dose methadone maintenance on cocaine place conditioning, cocaine self-administration, and mu-opioid receptor mRNA expression in the rat brain. Neuropsychopharmacology 2006, 31:1462-1474

16. Leri F, Zhou Y, Goddard B, Levy A, Jacklin D, Kreek MJ: Steady-state methadone blocks cocaine seeking and cocaine-induced gene expression alterations in the rat brain. Eur Neuropsychopharmaco/ 2009 19:238-249.

17. Mogenson GJ, Yim CC, Willner P, Scheel-Kruger J: Neuromodulatory functions of the mesolimbic dopamine system: electrophysiological and behavioural studies. In The mesolimbic dopamine system: from motivation to action. Edited by Wilner P, Scheel-Kruger J. West Sussex: John Wiley \& Sons; 1991:106-130. 
18. Stewart J: Pathways to relapse: the neurobiology of drug- and stress-induced relapse to drug-taking. J Psychiatry Neurosci 2000, 25:125-136.

19. Ghitza UE, Preston KL, Epstein DH, Kuwabara H, Endres CJ, Bencherif B, Boyd SJ, Copersino ML, Frost JJ, Gorelick DA: Brain mu-opioid receptor binding predicts treatment outcome in cocaine-abusing outpatients. Biol Psychiatry 2010, 68:697-703

20. Gorelick DA, Kim YK, Bencherif B, Boyd SJ, Nelson R, Copersino M, Endres CJ Dannals RF, Frost JJ: Imaging brain mu-opioid receptors in abstinent cocaine users: time course and relation to cocaine craving. Biol Psychiatry 2005, 57:1573-1582.

21. Zubieta JK, Gorelick DA, Stauffer R, Ravert HT, Dannals RF, Frost JJ: Increased mu opioid receptor binding detected by PET in cocaine-dependent men is associated with cocaine craving. Nat Med 1996, 2:1225-1229.

22. Lee DK, Koh WC, Shim YB, Shim I, Choe ES: Repeated cocaine administration increases nitric oxide efflux in the rat dorsal striatum. Psychopharmacology 2010, 208:245-256.

23. Sammut S, West AR: Acute cocaine administration increases NO efflux in the rat prefrontal cortex via a neuronal NOS-dependent mechanism. Synapse 2008, 62:710-713.

24. Chan SH, Chang KF, Ou CC, Chan JY: Nitric oxide regulates c-fos expression in nucleus tractus soliarii induced by baroreceptor activation via CGMP-dependent protein kinase and CAMP response element-binding protein phosphorylation. Mol Pharmacol 2004, 65:19-325.

25. Haby C, Lisovoski F, Aunis D, Zwiller J: Stimulation of the cyclic GMP pathway by NO induces expression of the immediate early genes c-fos and junB in PC12 cells. J Neurochem 1994, 62:496-501.

26. Imam SZ, Jankovic J, Ali SF, Skinner JT, Xie W, Conneely OM, Le WD: Nitric oxide mediates increased susceptibility to dopaminergic damage in Nurr1 heterozygous mice. FASEB J 2005, 19:1441-1450.

27. Kreuter JD, Mattson BJ, Wang B, You ZB, Hope BT: Cocaine-induced Fos expression in rat striatum is blocked by chloral hydrate or urethane. Neuroscience 2004, 127:233-242.

28. Morris BJ: Stimulation of immediate early gene expression in striatal neurons by nitric oxide. J Biol Chem 1995, 270:24740-24744

29. Pilz RB, Suhasini M, Idriss S, Meinkoth $J$, Boss GR: Nitric oxide and cGMP analogs activate transcription from AP-1 responsive promoters in mammalian cells. FASEB J 1995, 9:552-558.

30. Radwanska K, Caboche J, Kaczmarek L: Extracellular signal-regulated kinases (ERKs) modulated cocaine-induced gene expression in the mouse amygdala. Eur J Neurosci 2005, 22:939-948.

31. Zahm DS, Becker ML, Freiman AJ, Strauch S, Degarmo B, Geisler S, Meredith GE, Marinelli M: Fos after single and repeated self-administration of cocaine and saline in the rat: emphasis on the Basal forebrain and recalibration of expression. Neuropsychopharmacology 2010, 35:445-463.

32. Zhuravliova E, Barbakadze T, Narmania N, Ramsden J, Mikeladze D: Inhibition of nitric oxide synthase and farnesyltransferase change the activities of several transcription factors. J Mol Neurosci 2007, 31:281-287.

33. Börner C, Höllt V, Kraus J: Involvement of activator protein-1 in transcriptional regulation of the human mu-opioid receptor gene. Mol Pharmacol 2002, 61:800-805.

34. Feng J, Jing F, Fang $H, G u L, X u$ W: Expression, purification, and Snitrosylation of recombinant histone deacetylase 8 in Escherichia coli. Biosci Trends 2011, 5:17-22.

35. Sha $Y$, Marshall HE: S-nitrosylation in the regulation of gene transcription. Biochim Biophys Acta, in press [Epub ahead of print].

36. Hui B, Wang W, Li J: Biphasic modulation of cocaine-induced conditioned place preference through inhibition of histone acetyltransferase and histone deacetylase. Saudi Med J 2010, 31:389-393.

37. Sun J, Wang L, Jiang B, Hui B, Lv Z, Ma L: The effects of sodium butyrate, an inhibitor of histone deacetylase, on the cocaine- and sucrosemaintained self-administration in rats. Neurosci Letters 2008, 441:72-76.

38. Hwang CH, Song KY, Kim CS, Choi HS, Guo X, Law P, Wei L, Loh HH: Epigenetic programming of $\mu$-opioid receptor gene in mouse brain is regulated by $\mathrm{MeCP} 2$ and brg1 chromatin remodelling factor. J Cell Mol Med 2008, 13:3591-3615.

39. Hwang CK, Kim CS, do K K, Law PY, Wei LN, Loh HH: Up-regulation of the mu-opioid receptor gene is mediated through chromatin remodeling and transcriptional factors in differentiated neuronal cells. Mol Pharmacol 2010, 78:58-68.
40. Guan X, Tao J, Li S: Dopamine D1 receptor, but not dopamine D2 receptor, is a critical regulator for acute cocaine-enhanced gene expression. Neurol Res 2009, 31:17-22.

41. Jablonka E, Lachman M, Lamb MJ: Evidence, mechanisms and models for the inheritance of acquired characters. J Theor Biol 1992, 158:245-268.

42. Liu Y, Lu C, Yang Y, Fan Y, Yang R, Liu CF, Korolev N, Nordenskiöld L: Influence of Histone Tails and H4 Tail Acetylations on NucleosomeNucleosome Interactions. J Mol Biol 2011, 414:749-764.

43. Kwak Y, Ma T, Diao S, Zhang X, Chen Y, Hsu J, Lipton S, Masliah E, Xu H, Liao F: NO signaling and S-nitrosylation regulate PTEN inhibition in neurodegeneration. Mol Neurodegener 2010, 5:49-61.

44. Palmer LA, Gaston B, Johns RA: Normoxic stabilization of hypoxiainducible factor-1 expression and activity: redox-dependent effect of nitrogen oxides. Mol Pharmacol 2000, 58:1197-1203.

45. Schlake T, Klehr-Wirth D, Yoshida M, Beppu T, Bode J: Gene expression within a chromatin domain: the role of core histone hyperacetylation. Biochemistry 1994, 33:4197-4206.

46. Ura K, Kurumizaka H, Dimitrov S, Almouzni G, Wolffe AP: Histone acetylation: influence on transcription, nucleosome mobility and positioning, and linker histone-dependent transcriptional repression. EMBO J 1997, 16:2096-2107.

47. Zhou J, Fandrev J, Schiiman J, Tiegs G, Brüne B: NO and TNF- released from activated macrophages stabilize HIF-1 in resting tubular LLC-PK1 cells. Am J Physiol 2003, 284:C439-C446.

48. Borowitz $\lrcorner \mathrm{L}$, Gunasekar PG, Isom GE: Hydrogen cyanide generation by mu-opiate receptor activation: possible neuromodulatory role of endogenous cyanide. Brain Res 1997, 768:294-300.

49. Niu S, Kuo CH, Gan Y, Nisikawa E, Sadakata T, Ichikawa H, Miki N: Increase of calmodulin III gene expression by mu-opioid receptor stimulation in PC12 cells. Jpn J Pharmacol 2000, 84:412-417.

50. Yoshikawa M, Ueno S, Hirano M, Nakayama H, Furuya $H$ : Effects of fentanyl on survival of serum-deprived rat pehochromocytoma cells. Pharm Pharmacol Commun 1999, 5:603-607.

51. Baskey JC, Kalisch BE, Davis WL, Meakin SO, Rylett RJ: PC12 ${ }^{\text {nnr5 }}$ cells expressing TrkA receptors undergo morphological but not cholinergic phenotypic differentiation in response to NGF. J Neurochem 2002, 80:501-511

52. Binnington JC, Kalisch BE: Nitric oxide synthase inhibitors modulate nerve growth factor-mediated regulation of amyloid precursor protein expression in PC12 cells. J Neurochem 2007, 101:422-433.

53. Kalisch BE, Bock NA, Davis W, Rylett RJ: Inhibitors of nitric oxide synthase attenuate nerve growth factor-mediated increases in choline acetyltransferase gene expression in PC12 cells. J Neurochem 2002, 81:624-635.

54. Kalisch BE, Demeris CS, Ishak M, Rylett RJ: Modulation of nerve growth factor-induced activation of MAP kinase in PC12 cells by inhibitors of nitric oxide synthase. J Neurochem 2003, 87:1321-1332.

55. Gotfryd K, Skladchikova G, Lepekhin EA, Berezin V, Bock E, Walmod PS: Cell type-specific anti-cancer properties of valproic acid: independent effects on HDAC activity and Erk1/2 phosphorylation. BMC Cancer 2010, 10:383.

56. Imam SZ, Duhart HM, Skinner JT, Ali SF: Cocaine induces a differential dose-dependent alteration in the expression profile of immediate early genes, transcription factors, and caspases in PC12 cells: a possible mechanism of neurotoxic damage in cocaine addiction. Ann NY Acad SCi 2005, 1053:482-490

57. Unterwald EM, Cox BM, Kreek MJ, Cote TE, Izenwasser S: Chronic repeated cocaine administration alters basal and opioid-regulated adenylyl cyclase activity. Synapse 1993, 15:33-38.

58. Izenwasser S, Heller B, Cox BM: Continuous cocaine administration enhances mu- but not delta-opioid receptor-mediated inhibition of adenylyl cyclase activity in nucleus accumbens. Eur J Pharmacol 1996, 297:187-191.

59. Cheung NS, Pascoe CJ, Giardina SF, John CA, Beart PM: Micromolar L-glutamate induces extensive apoptosis in an apoptotic-necrotic continuum of insult-dependent, excitotoxic injury in cultured cortical neurones. Neuropharmacol 1998, 37:1419-1429.

60. Siddiqui MA, Kashyap MP, Kumar V, Tripathi VK, Khanna VK, Yadav S, Pant AB: Differential protection of pre-, co- and post-treatment of curcumin against hydrogen peroxide in PC12 cells. Hum Exp Toxicol 2011, 30:192-198.

61. Chen W, Bacanamwo M, Harrison DG: Activation of p300 histone acetyltransferase activity is an early endothelial response to laminar 
shear stress and is essential for stimulation of endothelial nitric-oxide synthase mRNA transcription. J Biol Chem 2008, 283:16293-16298.

62. Kang SK, Cha SH, Jeon HG: Curcumin-induced histone hypoacetylation enhances caspase-3-dependent glioma cell death and neurogenesis of neural progenitor cells. Stem Cells Dev 2006, 15:165-174.

63. Sun $H$, Yang $X$, Zhu J, Lv T, Chen Y, Chen G, Zhong L, Li Y, Huang $X$, Huang G, Tian J: Inhibition of p300-HAT results in a reduced histone acetylation and down-regulation of gene expression in cardiac myocytes. Life Sci 2010, 87:707-714.

64. Bradford M: A rapid and sensitive method for the quantitation of microgram quantities of protein utilizing the principle of protein-dye binding. Anal Biochem 1976, 72:248-254.

65. Mackinnon JC, Huether P, Kalisch BE: Effects of nerve growth factor and nitric oxide synthase inhibitors on amyloid precursor protein mRNA levels and protein stability. Open Biochem J 2012, 6:31-39.

66. Unterwald EM, Kreek MJ, Cuntapay M: The frequency of cocaine administration impacts cocaine-induced receptor alterations. Brain Res 2001, 900:103-109.

67. Larson EB, Akkentli F, Edwards S, Graham DL, Simmons DL, Alibhai IN, Nestler EJ, Self DW: Striatal regulation of $\triangle$ FosB, FosB, and cFos during cocaine self-administration and withdrawal. J Neurochem 2010, 115:112-122.

68. Bossis G, Malnou CE, Farras R, Andermarcher E, Hipskind R, Rodriguez M, Schmidt D, Muller S, Jariel-Encontre I, Piechaczyk M: Down-regulation of c-Fos/c-Jun AP-1 dimer activity by sumoylation. Mol Cell Biol 2005, 25:6964-6979.

69. Chinenov Y, Kerppola TK: Close encounters of many kinds: Fos-Jun interactions that mediate transcription regulatory specificity. Oncogene 2001, 20:2438-2452

70. Mattson BJ, Bossert JM, Simmons DE, Nozaki N, Nagarkar D, Kreuter JD, Hope BT: Cocaine-induced CREB phosphorylation in nucleus accumbens of cocaine-sensitized rats is enabled by enhanced activation of extracellular signal-related kinase, but not protein kinase A. J Neurochem 2005, 95:1481-1494

71. Mayr B, Montminy M: Transcriptional regulation by the phosphorylationdependent factor CREB. Nat Rev Mol Cell Biol 2001, 2:599-609.

72. Imam SZ, Duhart HM, Skinner JT, Ali SF: Cocaine induces a dosedependent alteration in the expression of immediate early genes c-fos and SP-1 and in nuclear factor NF-kappabeta in PC12 cells. Ann NY Acad Sci 2003, 993:362.

73. Lepsch LB, Munhoz CD, Kawamoto EM, Yshii LM, Lima LS, Curi-Boaventura MF, Salgado TM, Curi R, Planeta CS, Scavone C: Cocaine induces cell death and activates the transcription nuclear factor kappa-B in PC12 cells. Mol Brain 2009, 2:3.

74. Beltran JA, Peek J, Chang SL: Expression and regulation of the mu opioid peptide receptor in TPA-differentiated HL-60 promyelocytic leukemia cells. Int Immunopharmacol 2006, 6:1331-1340

75. Gach K, Piestrzeniewicz M, Fichna J, Stefanska B, Szemraj J, Janecka A: Opioid-induced regulation of mu-opioid receptor gene expression in the MCF-7 breast cancer cell line. Biochem Cell Biol 2008, 86:217-226.

76. Lin YC, Flock KE, Cook RJ, Hunkele AJ, Loh HH, Ko JL: Effects of trichostatin A on neuronal mu-opioid receptor gene expression. Brain Res 2008, 1246:1-10.

77. Pudiak CM, Bozarth MA: The effect of nitric oxide synthesis inhibition on intravenous cocaine self-administration. Prog Neuropsychopharmacol Biol Psychiatry 2002, 26:189-196.

78. Bhargava HN, Kumar S: Sensitization to the locomotor stimulant activity of cocaine is associated with increases in nitric oxide synthase activity in brain regions and spinal cord of mice. Pharmacol 1997, 55:292-298.

79. Yoo JH, Cho JH, Lee SY, Lee S, Loh HH, Ho IK, Jang CG: Differential effects of morphine- and cocaine-induced nNOS immunoreactivity in the dentate gyrus of hippocampus of mice lacking mu-opioid receptors. Neurosci Lett 2006, 395:98-102.

80. Collins SL, Kantak KM: Neuronal nitric oxide synthase inhibition decreases cocaine self-administration behavior in rats. Psychopharmacology (Berl) 2002, 159:361-369.

81. Itzhak Y, Martin JL, Black MD, Huang PL: The role of neuronal nitric oxide synthase in cocaine-induced conditioned place preference. Neuroreport 1998, 9:2485-2488.

82. Itzhak Y: Role of the NMDA receptor and nitric oxide in memory reconsolidation of cocaine-induced conditioned place preference in mice. Ann N Y Acad Sci 2008, 1139:350-357.
83. Martin JL, Itzhak Y: 7-Nitroindazole blocks nicotine-induced conditioned place preference but not LiCl-induced conditioned place aversion. Neuroreport 2000, 11:947-949.

84. Ohki K, Yoshida K, Hagiwara M, Harada T, Takamura M, Ohashi T, Matsuda $H$, Imaki J: Nitric oxide induces c-fos gene expression via cyclic AMP response element binding protein (CREB) phosphorylation in rat retinal pigment epithelium. Brain Res 1995, 696:140-144.

85. Riccio A, Alvania RS, Lonze BE, Ramanan N, Kim T, Huang Y, Dawson TM, Snyder SH, Ginty DD: A nitric oxide signaling pathway controls CREB-mediated gene expression in neurons. Mol Cell 2006, 21: 283-294.

86. Sanchis-Segura C, Lopez-Atalaya JP, Barco A: Selective boosting of transcriptional and behavioral responses to drugs of abuse by histone deacetylase inhibition. Neuropsychopharmacol 2009, 34:2642-2654.

87. Wang L, Lv Z, Hu Z, Sheng J, Hui B, Sun J, Ma L: Chronic cocaine-induced $\mathrm{H} 3$ acetylation and transcriptional activation of CaMKII alpha in the nucleus accumbens is critical for motivation for drug reinforcement. Neuropsychopharmacol 2010, 35:913-928.

88. Cearley CN, Blindheim K, Sorg BA, Krueger JM, Churchill L: Acute cocaine increases interleukin-1 $\beta$ mRNA and immunoreactive cells in the cortex and nucleus accumbens. Neurochem Res 2011, 36:686-692.

89. Zhang L, Belkowski JS, Briscoe T, Rogers TJ: Regulation of Mu Opioid Receptor Expression in Developing T Cells. J Neuroimmune Pharmacol 2012, [Epub ahead of print].

90. Buhrmann C, Mobasheri A, Busch F, Aldinger C, Stahlmann R, Montaseri A, Shakibaei M: Curcumin modulates nuclear factor kappaB (NF-kappaB)mediated inflammation in human tenocytes in vitro: role of the phosphatidylinositol 3-kinase/Akt pathway. J Biol Chem 2011, 286:28556-28566.

91. Gan Y, Shen YH, Utama B, Wang J, Coselli J, Wang XL: Dual effects of histone deacetylase inhibition by trichostatin $A$ on endothelial nitric oxide synthase expression in endothelial cells. Biochem Biophys Res Commun 2006, 340:29-34.

92. Thiriet N, Aunis D, Zwiller J: The nitric oxide releasing agent sodium nitroprusside modulates cocaine-induced immediate early gene expression in rat brain. Ann NY Acad Sci 2002, 965:47-54.

93. Kumar A, Choi KH, Renthal W, Tsankova NM, Theobald DE, Truong HT, Russo SJ, Laplant Q, Sasaki TS, Whistler KN, Neve RL, Self DW, Nestler EJ: Chromatin remodeling is a key mechanism underlying cocaine-induced plasticity in striatum. Neuron 2005, 48:303-314.

94. Miyamoto Y, Sakai R, Maeda C, Takata T, Ihara H, Tsuchiya Y, Watanabe Y. Nitric oxide promotes nicotine-triggered ERK signaling via redox reactions in PC12 cells. Nitric Oxide 2011, 25:344-349.

95. Yasui $\mathrm{H}$, Ito $\mathrm{N}$, Yamamori T, Nakamura $\mathrm{H}$, Okano J, Asanuma T, Nakajima T, Kuwabara M, Inanami O: Induction of neurite outgrowth by alpha-phenyl$\mathrm{N}$-tert-butylnitrone through nitric oxide release and Ras-ERK pathway in PC12 cells. Free Radic Res 2010, 44:645-654.

96. Jang $\mathrm{JH}$, Surh YJ: AP-1 mediates beta-amyloid-induced iNOS expression in PC12 cells via the ERK2 and p38 MAPK signaling pathways. Biochem Biophys Res Commun 2005, 331:1421-1428.

97. Kim TW, Lee CH, Choi CY, Kwon NS, Baek KJ, Kim YG, Yun HY: Nitric oxide mediates membrane depolarization-promoted survival of rat neuronal PC12 cells. Neurosci Lett 2003, 344:209-211.

98. Tan Z, Dohi S, Ohguchi K, Nakashima S, Nozawa Y: Local anesthetics inhibit muscarinic receptor-mediated activation of extracellular signal-regulated kinases in rat pheochromocytoma PC12 cells. Anesthesiology 1999, 91:1014-1024.

99. Kim S, Shin JK, Yoon HS, Kim JH: Blockade of ERK Phosphorylation in the Nucleus Accumbens Inhibits the Expression of Cocaine-induced Behavioral Sensitization in Rats. Korean J Physiol Pharmacol 2011, 15:389-395.

100. Self DW, Nestler EJ: Molecular mechanisms of drug reinforcement and addiction. Annu Rev Neurosci 1995, 18:463-495

101. Bashkatova V, Mathieu-Kia AM, Durand C, Penit-Soria J: Neurochemical changes and neurotoxic effects of an acute treatment with sydnocarb, a novel psychostimulant: comparison with D-amphetamine. Ann NY Acad Sci 2002, 965:180-192.

102. Broadbelt NV, Chen J, Silver RB, Poppas DP, Felsen D: Pressure activates epidermal growth factor receptor leading to the induction of iNOS via NFkappaB and STAT3 in human proximal tubule cells. Am J Physiol Renal Physiol 2009, 297:F114-F124. 
103. Hwang MH, Damte D, Lee JS, Gebru E, Chang ZQ, Cheng H, Jung BY, Rhee MH, Park SC: Mycoplasma hyopneumoniae induces pro-inflammatory cytokine and nitric oxide production through NFKB and MAPK pathways in RAW264.7 cells. Vet Res Commun 2011, 35:21-34.

104. Rang HP, Dale MM, Ritter JM: Local anaesthetics and other drugs that affect ion channels. In Pharmacology. 4th edition. Edinburgh: Harcourt Publishers Ltd; 2001:634-645.

doi:10.1186/2050-6511-13-11

Cite this article as: Winick-Ng et al: Nitric oxide and histone

deacetylases modulate cocaine-induced mu-opioid receptor levels in PC12 cells. BMC Pharmacology and Toxicology 2012 13:11.

\section{Submit your next manuscript to BioMed Central and take full advantage of:}

- Convenient online submission

- Thorough peer review

- No space constraints or color figure charges

- Immediate publication on acceptance

- Inclusion in PubMed, CAS, Scopus and Google Scholar

- Research which is freely available for redistribution 